\title{
Drosophila melanogaster: A Genome Sequenced
}

\author{
R. Scott Hawley ${ }^{1}$ and Michelle Y. Walker \\ Section of Molecular and Cellular Biology, University of California, Davis, Davis 95616 USA
}

$\mathbf{T}_{\mathrm{H}}$ he release of the full genome sequence of Drosophila melanogaster in March of 2000 must be heralded both as a milestone in Drosophila biology and genetics and as a triumph of modern biotechnology. But the true value of this accomplishment can be found in its beginnings, during a plenary session at a 1978 Drosophila meeting in La Jolla, California.

The first speaker of the session was peppered with questions as to whether investigators had "done the genetics" regarding the various natural polymorphisms he described. The second speaker, a future Nobel laureate, introduced himself with the response, "My name is Ed Lewis. I work on the Bithorax complex of genes, and yes, I've done the genetics." This rather astounding bit of understatement highlighted a talk that described studies of a developmentally critical set of genes at the highest genetic resolution possible in Drosophila. Building on those very elegant genetic studies, the next talk, given by David Hogness, truly opened the door to the future of Drosophila genetics. Hogness described a clear approach to the cloning and molecular analysis of the Bithorax complex. Those attending these talks got a first glimpse of the value of obtaining a molecular map of an interesting genetic region that could be properly annotated by decades of genetic analysis.

In the decades that followed this meeting, Hogness, Lewis, and their colleagues provided the promised maps and sequences of the Bithorax complex. Similar studies annotated the molecular

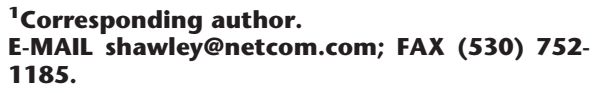

maps of other genetically wellcharacterized genes, such as white and $A d h$. In each case, the combination of molecular studies of the mutants with the phenotypic effects of those mutants provided truly synergistic insights into gene structure and function. As cloning and gene finding became possible in Drosophila, the number of such stories increased. By the early 1990s, the standard fly genetics paper would consist of getting the mutants, cloning and sequencing the gene, and correlating the molecular and genetic information. This mode of doing science usually reflected an enormous input of up-front labor in both isolating the right mutants and in the sometimes slow and tedious process of gene identification in Drosophila.

In that same decade, the focus of analysis clearly shifted from detailed studies of single genes to the desire to identify most, if not all, of the genes in a given process. The large-scale searches of Larry Sandler and Dan Lindsley for meiotic genes and of Christiane Nüsslein-Volhard and Eric Weischaus for developmentally important genes, changed the way fly genetics was done. The basic objective of the "new fly genetics" was less to study a given gene than it was to study as many genes as possible whose activity influenced a given biological process. This kind of approach necessitated a much more global approach to mutant hunting and gene identification in Drosophila. People like Gerry Rubin, Allan Spradling, Michael Ashburner, Thom Kaufman and others began talking about the need to clone and identify, as well as to obtain mutants in, all of the genes in Drosophila.The value of such an approach in Drosophila was underscored by the fact that there were whole regions of chromosomes for which saturation mutagenesis had been accomplished. Indeed, this could even be said to be true for the entire fourth chromosome.

Nonetheless, many uncharacterized regions remained, and the effort required for even small saturation studies was enormous. Although a number of tools became available for improving transposon-based mutagenesis, the problem of gene finding still occupied a large amount of time for many investigators.

It is in this context, of both enormous existing genetic resources and a desire to characterize the entire genome, that the recent release of the entire Drosophila sequence must be discussed. The value of that sequence will lie as much in the annotation as it will in the raw resource of the sequence itself. It will clearly be valuable to rapidly identify fly homologs of a given mammalian gene, but the real payoff will be the use of the annotation to quickly identify existing mutants in that gene. Moreover, recent developments that will facilitate large-scale, locallydirected mutagenesis in Drosophila raise our confidence that the "chicken in every pot" promise of a "transposon in every gene" can actually be fulfilled. Thanks to the work of Gary Karpen, Steve Henikoff, Barbara Wakimoto and their collaborators, even the once forbidding dark castles of the centric heterochromatin are now accessible to this dual genetic and molecular analysis.

The completion of the sequence will open whole new areas of research and 
facilitate those currently existing. Less of our time will be spent in gene finding, with a compensatory increase on the time and energy available for detailed genetic analysis. As such analysis is done, the annotation will improve and the sequence will continuously increase in value. The combination of detailed sequence annotation with the ability to analyze gene expression at a genomewide level using microchips displays the utility of D. melanogaster in a whole new light. The little fly whose genetics proved the chromosome theory and began the study of the functional anatomy of single genes now has be- come an ideal tool for functional genomics.

In that sense, the real value of the acquisition of the full sequence by Gerry Rubin, Craig Venter, and their colleagues rests in the fact that for the last century the Drosophila community has "done the genetics." 


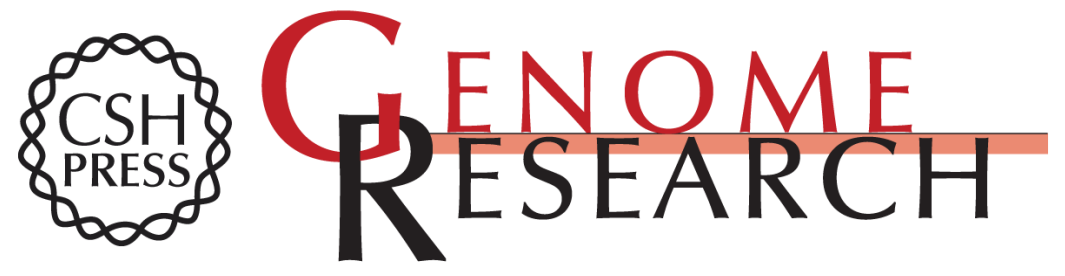

\section{Drosophila melanogaster: A Genome Sequenced}

R. Scott Hawley and Michelle Y. Walker

Genome Res. 2000 10: 593-594

Access the most recent version at doi:10.1101/gr.10.5.593

\section{License}

Email Alerting Receive free email alerts when new articles cite this article - sign up in the box at the Service top right corner of the article or click here.

\section{Affordable, Accurate Sequencing.}

To subscribe to Genome Research go to:

https://genome.cshlp.org/subscriptions 